\title{
Diagnosis dan Tatalaksana Benign Paroxysmal Positional Vertigo (BPPV) Horizontal Berdasarkan Head Roll Test
}

\author{
Yan Edward, Yelvita Roza
}

\begin{abstract}
Abstrak
Latar belakang: Benign Paroxysmal Positional Vertigo (BPPV) merupakan vertigo yang dicetuskan oleh perubahan posisi kepala atau badan terhadap gaya gravitasi. Diagnosis BPPV ditegakkan berdasarkan anamnesis dan manuver provokasi. Sering kali terjadi kesalahan dalam menegakkan diagnosis BPPV yang berakibat terhadap penatalaksanaan vertigo yang tidak adekuat. Tujuan: Untuk menjelaskan bagaimana diagnosis dan tatalaksana BPPV Kanalis Horizontal. Kasus: Seorang laki-laki berusia 56 tahun yang didiagnosis sebagai BPPV Kanalis Horizontal kiri tipe kanalolithiasis apogeotropik. Penatalaksanaan: Dilakukan barbeque maneuver terapi reposisi kanalith. Kesimpulan: Penatalaksanaan BPPV adalah berdasarkan lokasi kanal yang terlibat dengan terapi reposisi kanalith.

Kata kunci: BPPV, kanalis horizontal, kanalolithiasis apogeotropik.
\end{abstract}

\begin{abstract}
Background: Benign Paroxysmal Positional Vertigo (BPPV) is vertigo that provoked by a position change of the head or body to the gravitation. The diagnosis of BPPV can be established by anamnesis and provocation maneuver. However, because BPPV frequently is misdiagnosed, it will implicate to an adequate therapeutic. Purposes: Explaining how to diagnose and manage a Horizontal Canal BPPV. Case : a man, 56 ages which diagnosed as a Left Horizontal Canal BPPV apogeotropic canalolithiasis type. Management: A barbeque maneuver was performed as canalith reposition treatment. Conclution: The management of BPPV is based on the involved canal with canalith repositioning treatment.
\end{abstract}

Keywords: BPPV, horizontal canal, apogeotropic canalolithiasis.

Affiliasi penulis : Bagian THT-KL Fakultas Kedokteran Universitas Andalas,

Korespondensi : Yan Edward, Yelvita Roza, email Yelvitaroza.yr@gmail.com, Telp: 0751-810900

\section{Pendahuluan}

Benign Paroxysmal Positional Vertigo (BPPV)

adalah gangguan vestibuler yang paling sering ditemui, dengan gejala rasa pusing berputar diikuti mual muntah dan keringat dingin, yang dipicu oleh perubahan posisi kepala terhadap gaya gravitasi tanpa adanya keterlibatan lesi di susunan saraf pusat. ${ }^{1-7}$

Pada umumnya BPPV melibatkan kanalis semisirkularis posterior dengan angka resolusi lebih dari 95\% setelah terapi reposisi kanalith. Beberapa tahun terakhir, terdapat peningkatan laporan insiden BPPV kanalis horizontal, namun dengan angka kesuksesan terapi yang masih rendah (<75\%). Hal ini disebabkan kesalahan dalam penentuan letak lesi dan tipe BPPV kanalis horizontal. ${ }^{6,10,12-14}$

Pasien dengan keluhan dan gejala yang sesuai dengan BPPV, namun tidak sesuai dengan kriteria diagnostik BPPV kanalis posterior, harus dicurigai sebagai BPPV kanalis horizontal. ${ }^{6,7,15}$

Sekitar 50\%, penyebab BPPV adalah idiopatik, selain idiopatik, penyebab terbanyak adalah trauma kepala (17\%) diikuti dengan neuritis vestibularis (15\%), migraine, implantasi gigi dan operasi telinga, dapat juga sebagai akibat dari posisi tidur yang lama pada pasien post operasi atau bed rest total lama. 2,8,16

Pada sebuah klinik vertigo di London, Inggris ditemukan sebanyak 17\% kasus BPPV dari semua keluhan vertigo. Keterlibatan kanalis semisirkularis horizontal hanya sekitar $10-30 \%$ dari semua BPPV. ${ }^{4,10,15}$

Hain T dan Escher dalam penelitian masing masing memperkirakan angka kejadian BPPV kanalis horizontal hanya sebanyak $3-12 \%$ pertahunnya dengan kasus terbanyak tipe kanalolithiasis (75\%). ${ }^{16,17}$ Cakir dkk, melaporkan angka kejadian BPPV kanalis horizontal sebanyak $13.6 \%$ dari seluruh kasus BPPV yang ditelitinya dari bulan November 2001 sampai Desember 2004, dimana nistagmus geotropik terlihat pada $73.9 \%$ kasus, dan nistagmus apogeotropik terlihat pada $26.1 \%$ kasus. $^{15} \mathrm{Hal}$ senada juga dilaporkan oleh Chiau Wen-Yaw dkk dalam penelitiannya di Taiwan pada tahun $2005 .{ }^{5}$ Chung dkk dalam penelitiannya di Seoul Korea Selatan (2009) melaporkan insidensi BPPV kanalis horizontal lebih tinggi pada penderita yang berobat dalam waktu 24 jam sejak timbulnya serangan pertama kali (40.5\%), $30.3 \%$ pada pasien dengan onset antara 24 jam sampai tujuh hari setelah serangan pertama dan $26.4 \%$ pada pasien yang dievaluasi setelah tujuh hari dari onset serangan vertigo pertamanya. Nistagmus geotropik ditemukan pada 130 kasus, dan nistagmus apogeotropik ditemukan sebanyak 78 kasus. ${ }^{10}$

BPPV kanalis horizontal adalah suatu bentuk varian dari BPPV yang pertama kali diperkenalkan oleh McClure tahun 1985 dengan karakteristik vertigo posisional yang diikuti nistagmus horizontal berubah arah. Arah nistagmus horizontal yang terjadi dapat berupa geotropik (arah gerakan fase cepat ke arah telinga di posisi bawah) atau apogeotropik (arah gerakan fase cepat ke arah telinga di posisi atas) selama kepala dipalingkan ke salah satu sisi dalam posisi telentang. Nistagmus geotropik terjadi karena adanya otokonia yang terlepas dari utrikulus dan 
masuk ke dalam lumen posterior kanalis horizontal (kanalolithiasis), sedangkan nistagmus apogeotropik terjadi karena otokonia yang terlepas dari utrikulus menempel pada kupula kanalis horizontal (kupulolithiasis) atau karena adanya fragmen otokonia di dalam lumen anterior kanalis horizontal (kanalolithiasis apogeotropik). ${ }^{4-10,12,14,15,18}$

Berdasarkan hukum Ewald kedua, stimulas ampulopetal lebih kuat daripada stimulasi ampulofugal pada kanalis semisirkularis horizontal. Arah putaran kepala yang mengakibatkan intensitas vertigo dan nistagmus yang kuat akan menunjukkan letak telinga yang sakit pada nistagmus geotropik dan telinga yang sehat pada nistagmus apogeotropik. ${ }^{4-10,12,18,19}$
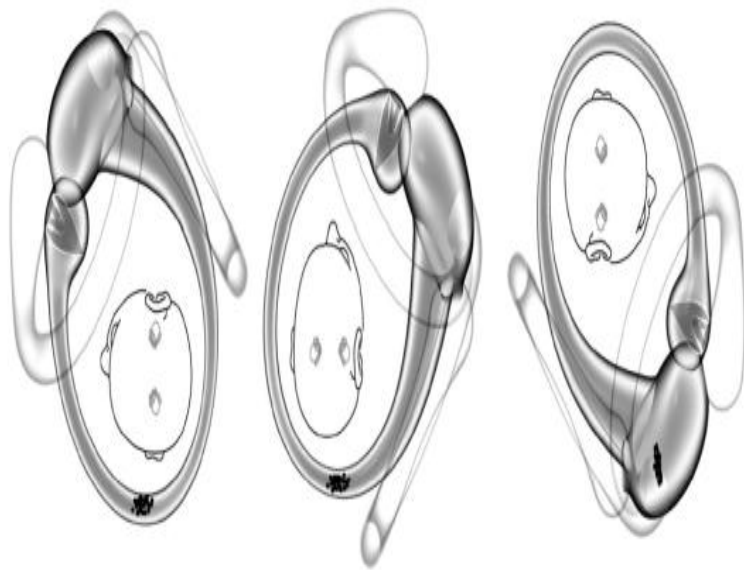

Gambar 1. BPPV kanalis horizontal dengan nistagmus geotropik kiri. ${ }^{14}$
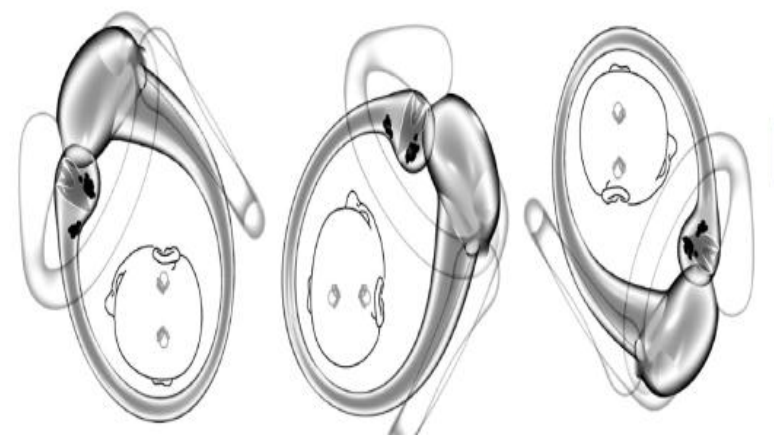

Gambar 2. BPPV kanalis horizontal dengan nistagmus apogeotropik kiri. ${ }^{14}$

Pasien dengan BPPV sering mengeluhkan rasa pusing berputar diikuti oleh mual, muntah dan keringat dingin sewaktu merubah posisi kepala terhadap gravitasi, dengan periode vertigo yang episodik dan berlangsung selama satu menit atau kurang. Pasien akan memodifikasi atau membatasi gerakan untuk menghindari episode vertigo. Dalam anamnesis, harus ditanyakan faktor-faktor yang merupakan etiologi atau yang dapat mempengaruhi keberhasilan terapi, seperti riwayat stroke, diabetes, hipertensi, trauma kepala, migrain dan riwayat gangguan keseimbangan sebelumnya atau riwayat gangguan saraf pusat.

Anamnesis BPPV dikonfirmasi dengan melakukan manuver provokasi untuk memastikan adanya keterlibatan kanalis semisirkularis. Sebelum melakukan manuver provokasi, haruslah diinformasikan kepada pasien bahwa tindakan yang dilakukan bertujuan untuk memprovokasi serangan vertigo. $^{14}$
BPPV kanalis semisirkularis horizontal dapat dideteksi dengan menggunakan manuver head roll test. Head roll test dilakukan dengan memutar kepala pasien $90^{\circ}$ ke sisi kiri atau kanan pada posisi telentang dengan mengangkat kepala $30^{\circ}$ dari garis horizontal bumi, sambil mengobservasi nistagmus yang ditimbulkan. Setelah nistagmus yang muncul menghilang, kepala pasien kembali menghadap posisi semula (wajah menghadap keatas dalam posisi telentang), pada posisi ini dapat muncul kembali nistagmus, setelah nistagmus tambahan hilang, kepala pasien dengan cepat dipalingkan $90^{\circ}$ kearah berlawanan, observasi nistagmus yang muncul. Nistagmus yang muncul pada waktu melakukan manuver head roll test menggambarkan tipe BPPV kanalis horizontal. ${ }^{2-8,12-15,28,29}$ Jika vertigo dan nistagmus yang muncul pada manuver head roll test mempunyai intensitas yang sama antara telinga kiri dan kanan, maka letak telinga yang sakit ditentukan dengan manuver lainnya yang tidak membandingkan intensitas dari vertigo dan nistagmus dengan bantuan elektronistagmografi (ENG), seperti bow and lean test, dan lying down dan head bending nystagmus ${ }^{10,18}$

American Academy of Otolaryngology-Head and Neck Surgery tidak merekomendasikan maneuver head roll test pada pasien dengan kemampuan fisik terbatas, seperti stenosis servikal, kyposcoliosis berat, ruang gerak servikal yang terbatas, down syndrome, rheumatoid arthritis berat, cervical radiculopathies, Paget's disease, morbid obesity, ankylosing spondylitis, low back dysfunction dan trauma medulla spinalis. Sampai saat ini, belum ditemukan adanya laporan tentang bahaya atau trauma yang sebabkan oleh manuver head roll test. ${ }^{6}$

Pemeriksaan audiometri tidak mempengaruhi diagnosis BPPV. Hearing loss dapat muncul pada pasien dengan BPPV, namun tidak mempengaruhi diagnosis dan terapi BPPV. Pemeriksaan elektronistagmografi (ENG) dapat membantu membedakan vertigo oleh karena kelainan di sentral atau perifer. Terapi medikamentosa kurang memberikan hasil yang memuaskan untuk tatalaksana BPPV. Terapi medikamentosa diberikan pada pasien dengan serangan vertigo yang disertai mual muntah hebat, sehingga belum memungkinkan untuk dilakukan tindakan maneuver diagnostik. Preparat yang diberikan adalah golongan vestibular depresan disertai anti emetik. $2,6,7,20$

Terapi BPPV tergantung pada patofisologi dan jenis kanal yang terlibat. Tujuan terapi adalah melepaskan otokonia dari dalam kanalis atau kupula, mengarahkan agar keluar dari kanalis semisirkularis menuju utrikulus melalui ujung non ampulatory kanal. $^{2,5-8,10,21,22}$

$$
\text { Beberapa teknik manuver telah }
$$
dikembangkan untuk menangani BPPV kanalis horizontal.

\section{Barbeceau Manuver ${ }^{1-8,10,18,21}$}

Pasien diminta untuk berputar $360^{\circ}$ dalam posisi tidur, dimulai dengan telinga yang sakit diposisi bawah, berputar $90^{\circ}$ sampai satu putaran lengkap $\left(360^{\circ}\right)$. Setiap posisi dipertahankan selama 30 detik. Manuver ini akan menggerakkan otokonia keluar dari kanal menuju utrikulus kembali. 


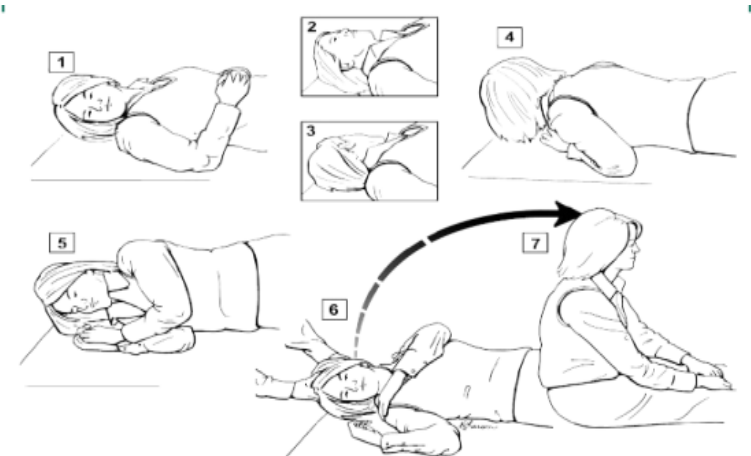

Gambar 3. Barbecue Manuver'

2. Log Roll maneuver 3,17

Pasien berputar $270^{\circ}$ dalam posisi tidur miring ke sisi telinga yang sakit, berputar $90^{\circ}$ tiap satu menit menuju ke telinga yang sehat dengan total putaran $270^{\circ}$

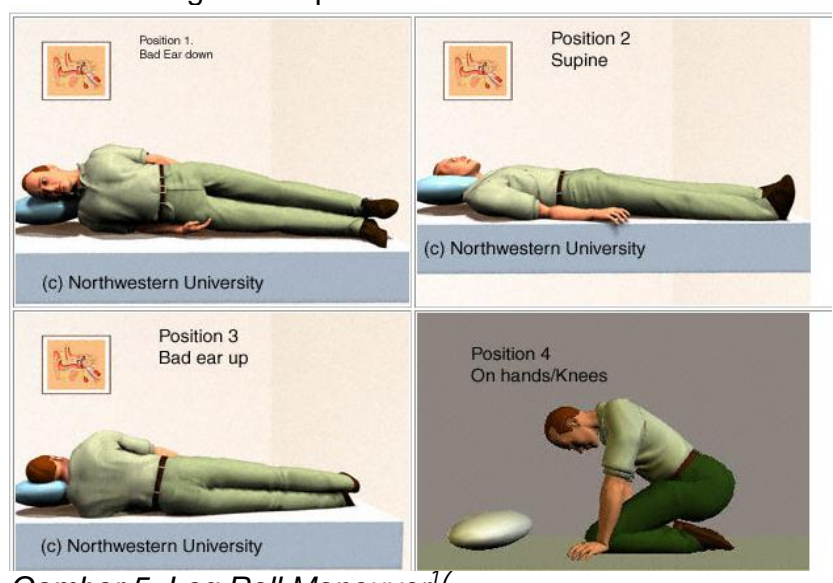

Gambar 5. Log Roll Maneuver

3. Gufoni Maneuver $6,7,18,19$

Pasien duduk dengan kepala menghadap lurus ke depan dan direbahkan dengan cepat ke arah sisi lesi, posisi ini dipertahankan selama satu menit setelah nistagmus apogeotropik berakhir. Dalam posisi rebah, kepala pasien diputar $45^{\circ} \mathrm{ke}$ depan (hidung ke atas), posisi ini dipertahankan selam dua menit. Pasien kembali ke posisi semula. Terapi ini diharapkan mampu mengkonversi nistagmus apogeotropik menjadi nistagmus geotropik

4. Forced Prolonged Position Maneuver ${ }^{6,8,18}$

Pasien diminta untuk tidur miring dengan telinga yang sakit berada di posisi atas selama 12 jam. Posisi ini diharapkan mampu melepaskan otokonia yang melekat pada kupula, dan memasukkan otokonia ke utrikulus kembali dengan bantuan gravitasi.

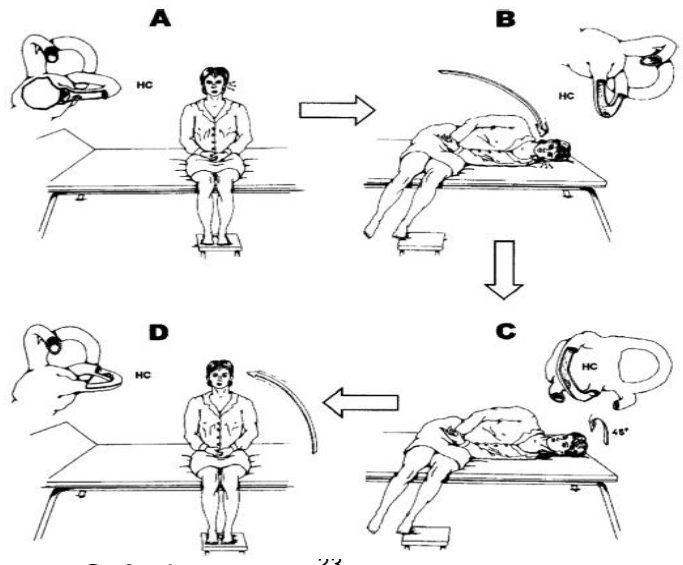

Gambar 6. Gufoni maneuveri3

Barbecue maneuver adalah manuver terapi yang paling banyak digunakan para klinisi untuk BPPV kanalis horizontal tipe kanalolithiasis maupun kupulolithiasis, namun sampai saat ini belum ditemukan laporan yang membandingkan efektifitas masing-masing teknik. ${ }^{6,}$

Penatalaksanaan BPPV kanalis horizontal tipe kupulolithiasis sampai saat ini masih merupakan tantangan tersendiri bagi para klinisi. Prinsip penatalaksanaan tipe kupulolithiasis adalah melepaskan otokonia dari kupula, dan memasukkannya kembali ke utrikulus. Hal ini dapat diketahui dengan berubahnya nistagmus apogeotropik menjadi geotropik. ${ }^{10,18,19,22}$

Keberhasilan terapi di konfirmasi dengan melakukan manuver provokasi ulang, jika masih terdapat gejala vertigo dan nistagmus, maka manuver terapi diulang kembali. Umumnya pada manuver provokasi yang ketiga, gejala vertigo dan nistagmus tidak muncul lagi. ${ }^{8,}$

Keberhasilan terapi pada BPPV digolongkan atas tiga kriteria ${ }^{6,9}$

1. Asimptomatis; pasien tidak lagi mengeluhkan rasa pusing berputar, dan head roll test tidak lagi memberikan gambaran nistagmus.

2. Perbaikan; secara subjektif keluhan vertigo telah berkurang lebih dari $70 \%$, pasien mampu melakukan aktifitas yang sebelumnya dihindari. Secara objektif nistagmus horizontal masih muncul pada manuver provokasi.

3. tidak ada perbaikan; jika keluhan vertigo yang dirasakan berkurang $<70 \%$, dan nistagmus muncul dengan intensitas yang sama.

BPPV kanalis horizontal beremisi lebih cepat dan lebih baik daripada BPPV posterior, hal ini dikarenakan posisi ujung kanalis semisirkularis horizontal yang terbuka dan sejajar dengan utrikulus sewaktu kepala berada pada posisi sejajar bidang 
horizontal bumi, sehingga otokonia yang berada di sepanjang kanalis dapat kembali spontan ke utrikulus. ${ }^{2-5}$

\section{LAPORAN KASUS}

Seorang laki-laki, Tn. A, umur 56 tahun, bekerja sebagai seorang eksekutif di perusahaan swasta, datang ke poliklinik THT-KL sub-bagian Neurotologi RS. Dr. M. Djamil Padang pada tanggal 20 Maret 2010 dengan keluhan rasa pusing berputar sejak 3 hari yang lalu. Rasa pusing berputar pertama kali dirasakan pasien sewaktu baru bangun dari tidur, pada waktu rukuk dan bersujud sewaktu shalat subuh. Pasien merasakan lingkungan disekelilingnya berputar, diikuti oleh mual dan muntah disertai keringat dingin. Rasa berputar berlangsung sekitar 1 2 menit dan hilang dengan sendirinya. Intensitas serangan makin lama makin berkurang, hilang timbul, muncul jika pasien berubah posisi, terutama jika pasien tidur miring ke kiri. Tidak ada riwayat penurunan pendengaran, tidak ada riwayat telinga berdengung, tidak ada riwayat trauma kepala sebelumnya, kelainan darah, diabetes dan hipertensi. Tidak ditemukan riwayat gangguan keseimbangan sebelumnya, penggunaan obat-obatan jantung, paru, ginjal dan malaria. Pasien mempunyai kebiasaan tidur miring ke kiri.

Pada pemeriksaan fisik didapatkan keadaan umum baik, komposmentis kooperatif, dan gizi baik. Tekanan darah $120 / 80 \mathrm{mmHg}$, nadi $86 \mathrm{x} /$ menit, frekwensi nafas $18 \mathrm{x} /$ menit.

Pemeriksaan telinga hidung dan tenggorok dalam batas normal. Tes penala memberi kesan normal, dan dipastikan dengan hasil audiogram dalam batas normal. Pemeriksaan Laboratorium rutin dan gambaran faal hemostasis, pemeriksaan keseimbangan sederhana (tes Romberg, Romberg dipertajam, Stepping test, Nose to finger test, Past Pointing test, disdiadokinesis), Ro foto servikal AP dan Lateral, memberikan kesan normal.

Pemeriksaan dilanjutkan dengan melakukan manuver Dix-Hallpike, tidak ditemukan keluhan vertigo dan nistagmus pada Dix-Halpike kanan dan kiri. Pemeriksaan dilanjutkan dengan manuver head roll test, dimulai dengan kepala ditolehkan ke kanan, tidak ditemukan adanya vertigo dan nistagmus. Pada waktu dilakukan manuver head rol test ke kiri, setelah lebih kurang sepuluh detik, pasien mengeluhkan rasa pusing berputar yang hebat, dan terlihat adanya nistagmus horizontal dengan fase cepat ke arah kanan. Pasien tidak dapat menahan muntah yang disertai keringat dingin sehingga head roll test tidak dilanjutkan. Pasien diistirahatkan lebih kurang setengah jam.

Ditegakkan diagnosis BPPV kanalis horizontal kiri tipe kanalolithiasis apogeotropik, dan diberikan terapi reposisi kanalith dengan barbecue maneuver, dimulai dari sisi telinga yang sakit. Rasa pusing berputar yang dirasakan pasien tetap sehebat yang pertama, tapi pasien mampu menjalaninya sampai rasa pusing berputar hilang, kepala pasien diputar $90^{\circ}$ ke kanan (hidung menghadap ke atas). Pasien merasakan rasa pusing berputar dan setelah 53 detik, pasien muntah kembali. Diputuskan untuk tidak melanjutkan terapi reposisi kanal. Untuk keluhan simptomatik, pasien diberikan terapi betahistin messilat satu tablet 2 kali sehari, dianjurkan untuk tidur miring ke sisi kanan dengan kepala ditinggikan $30^{\circ}$. Pasien diminta untuk kontrol 2 hari kemudian.

\section{Maret 2010.}

Pasien masih mengeluhkan rasa pusing berputar pada waktu bangun dari tidur, rukuk dan sujud, namun dengan intensitas yang lebih ringan, sehingga masih takut untuk menggerakkan kepala.

Kembali dilakukan manuver head roll test. Pada manuver head roll test kearah kiri, pasien merasakan pusing berputar dengan intensitas yang lebih ringan dibanding sebelumnya, tidak disertai dengan mual muntah dan keringat dingin, nistagmus horizontal dengan fase cepat ke arah kanan masih terlihat pada pada waktu telinga kirir berada pada posisi bawah. Head roll test kemudian dilanjutkan dengan barbecue maneuver untuk mereposisi otokonia yang berada di kanalis horizontal kiri. Dirumah tetap dianjurkan tidur dengan posisi miring ke kanan. Pasien dianjurkan kontrol tiga hari kemudian.

\section{5 maret 2010.}

Pasien masih mengeluhkan rasa pusing berputar, tapi telah jauh berkurang, pusing terasa jika bangun dari tidur.

Kembali dilakukan head roll test. Pasien masih mengeluhkan adanya rasa pusing berputar sewaktu telinga kiri di posisi bawah, nistagmus horizontal masih muncul, tapi dengan intensitas yang jauh telah berkurang. Dilakukan log roll maneuver untuk mengatasi gejala sisa yang masih ada. Pasien diminta untuk kontrol 1 minggu kemudian.

\section{1 maret 2010}

Keluhan rasa pusing berputar tidak lagi dirasakan pasien, tapi pasien masih cemas untuk menggerakkan kepalanya atau tidur miring ke kiri.

Head roll test yang dilakukan tidak menimbulkan vertigo dan nistagmus. Diputuskan untuk tidak melakukan manuver terapi, pasien masih dianjurkan untuk tidur dengan posisi miring ke kanan sampai 2 minggu bebas serangan. Sampai saat ini keluhan rasa pusing berputar tidak lagi dirasakan pasien.

\section{DISKUSI}

Telah dilaporkan sebuah kasus BPPV kanalis horizontal kiri dengan tipe kanalolithiasis apogeotropik yang terjadi pada seorang laki-laki berusia 56 tahun. Etiologi pada pasien ini adalah idiopatik, yang merupakan etiologi terbanyak untuk kasus BPPV. ${ }^{2,8,16}$

Diagnosis BPPV kanalis horizontal kiri ditegakkan berdasarkan anamnesis adanya keluhan rasa pusing berputar sewaktu posisi kepala berubah, diikuti dengan gejala mual muntah dan keringat dingin. Tes provokasi dengan manuver head roll test menimbulkan vertigo hebat sewaktu kepala dimiringkan kekiri dengan nistagmus apogeotropik yang muncul sesudah 10 detik dan mengalami penurunan intensitas dengan pengulangan manuver.

Menurut Heidenreich dkk, nistagmus geotropik kiri muncul pada waktu tes provokasi karena otokonia yang berada pada bagian posterior kanal bergerak ke arah kupula sewaktu telinga kiri berada di bawah, sehingga mengakibatkan nistagmus horizontal dengan fase cepat ke kiri. Pada nistagmus apogeotropik kiri, otokonia berada pada bagian anterior kanalis horizontal kiri, atau melekat pada kupula, sehingga kupula menjadi lebih sensitif terhadap gravitasi, mengakibatkan nistagmus horizontal dengan arah fase cepat ke kanan sewaktu telinga kiri berada pada posisi bawah. ${ }^{12,14,18,19}$ 
Nistagmus apogeotropik pada tipe kupulolithiasis tidak mempunyai fase laten, intensitas menetap selama kepala berada pada posisi provokatif dan tidak mempunyai fatigabilitas. Sebaliknya nistagmus apogeotropik pada tipe kanalolithiasis akan memperlihatkan adanya fase laten sebelum onset vertigo dengan onset yang lebih singkat sekitar satu menit dan mempunyai fatigabilitas. Kedua hal diatas sangat penting untuk dibedakan karena merupakan $\underset{10,12,18}{\text { dasar }}$ penentuan letak lesi dan awal manuver terapi. ${ }^{4}$

Posisi telinga yang sakit ditentukan dengan membandingkan intensitas vertigo dan nistagmus serta arah dari fase cepat nistagmus. Pada pasien yang tidak memperlihatkan perbedaan intensitas yang bermakna, atau dengan intensitas yang sama antara kiri dan kanan, letak lesi dapat ditentukan dengan maneuver bow and lean test atau lying down dan head-bending nystagmus, yaitu dengan menentukan arah nistagmus., 10,12,18,19

Manuver Dix-Hallpike yang dilakukan pada pasien ini tidak menimbulkan gejala vertigo, sehingga bisa disimpulkan bahwa tidak ada otokonia pada kanalis posterior dan anterior. Secara statistik, BPPV yang paling banyak ditemui adalah BPPV kanalis posterior, keterlibatan kanalis horizontal dilaporkan berkisar $10-30 \%$ dari jumlah BPPV. Hal ini dapat terjadi karena BPPV kanalis horizontal dapat beremisi spontan pada waktu kepala sejajar dengan bidang horizontal bumi. ${ }^{4-6,8-11}$

Menurut guidelines yang dikeluarkan AAOHNS pada tahun 2008, pasien dengan gejala khas BPPV tapi dengan Dix-Hallpike yang negatif pada waktu tes provokasi, haruslah dilanjutkan dengan head roll test, karena manuver Dix-Hallpike bukanlah manuver provokasi yang terbaik untuk BPPV kanalis horizontalis. ${ }^{6.7}$

BPPV kanalis horizontal dapat ditatalaksana dengan berbagai macam manuver terapi, namun yang terbanyak dan paling umum dipakai dan yang terdapat dalam modul perhati $\mathrm{KL}$ untuk tatalaksana BPPV kanalis horizontal adalah barbecue maneuver dengan efektifitas $>85 \%$. ${ }^{1-8.10,16}$,

Barbecue maneuver dapat dilakukan untuk BPPV kanalis horizontal tipe kanalolithiasis dan kupulolithiasis. Pada tipe kanalolithiasis, putaran barbecue dilakukan mulai dengan telinga sakit berada diposisi bawah, yaitu telinga dimana intensitas vertigo dan nistagmus yang terjadi lebih kuat kearah telinga yang sehat, sementara pada kupulolithiasis putaran barbecue dilakukan pada telinga yang memperlihatkan intensitas vertigo dan nistagmus yang lebih lemah diposisi bawah, ke telinga dengan intensitas vertigo dan nistagmus yang kuat. Pada pasien ini, walaupun nistagmus yang muncul merupakan nistagmus apogeotropik, akan tetapi mempunyai karakteristik yang sesuai dengan tipe kanalolithiasis, sehingga putaran barbecue maneuver tetap dimulai dari telinga yang memperlihatkan vertigo dan nistagmus dengan intensitas yang kuat pada waktu berada diposisi bawah $1-8.10,21$

Pada waktu pertama kali dilakukan manuver terapi, pasien tidak mampu menyelesaikan satu putaran barbecue, karena rasa pusing berputar dan gejala otonom yang muncul begitu hebat, sehingga diputuskan untuk tidak melanjutkan terapi dan diberikan pengobatan vestibulodepresan serta nasehat agar tidur miring dengan telinga yang sakit berada di posisi atas (Forced Prolonged Position/FPP) selama 12 jam, dengan FPP, diharapkan otokonia yang berada pada bagian anterior kanalis horizontal dapat bergerak ke bagian posterior dengan bantuan gravitasi. $2,6,7,18-20$

Barbecue maneuver pada pasien ini pertama kali dapat dilakukan secara lengkap pada waktu pasien datang kontrol pertama, yaitu dua hari kemudian. Pada saat ini pasien masih merasakan pusing berputar sewaktu perubahan posisi, walaupun tidak sehebat yang pertama namun pasien masih takut untuk menggerakkan kepalanya. Terlihat bahwa terapi medikamentosa yang diberikan tidak memberikan respon yang memuaskan, sesuai dengan literatur dimana pilihan terapi untuk BPPV adalah terapi reposisi kanalith. ${ }^{2,6,7,18-20}$

Respon dari manuver terapi yang dilakukan dievaluasi tiga hari berikutnya, dimana rasa pusing berputar yang dirasakan pasien telah berkurang lebih dari $70 \%$, pusing hanya terasa pada saat bangun dari tidur. Head roll test masih memprovokasi terjadinya vertigo dan nistagmus apogeotropik, namun dengan intensitas yang telah jauh berkurang. Pasien mampu menyelesaikan satu putaran lengkap log roll maneuver dan mengalami perbaikan dengan terapi yang diberikan. $6,7,8,10,18,19$,

Barbecue maneuver dan log roll maneuver mempunyai prinsip terapi yang sama, yaitu mendorong otokonia untuk kembali ke utrikulus melalui ujung non ampulatory kanal dengan bantuan gravitasi. $2,18,19$

Kontrol ketiga yang dilakukan satu minggu kemudian tidak lagi menimbulkan vertigo dan nistagmus dengan manuver head roll test, sehingga manuver terapi tidak dilakukan lagi. Keberhasilan terapi telah sampai pada kategori asimptomatis. Pasien tetap dianjurkan untuk tidur miring ke telinga yang sehat sampai 2 minggu bebas gejala, sesuai dengan literatur yang menganjurkan forced prolonged position dilakukan sampai 2 minggu setelah tidak ditemukannya lagi nistagmus dan vertigo pada tes provokasi. ${ }^{6,8,16,18,19}$

Tipe kanalolithiasis adalah kasus BPPV kanalis horizontal yang lebih sering terjadi daripada tipe kupulolithiasis dan merupakan tipe BPPV kanalis horizontal yang lebih respon terhadap manuver terapi daripada tipe kupulolithiasis.

\section{Daftar Pustaka}

1. Gananca FF, Gananca CF, Caovilla HH, Gananca MM, Albernaz PLM. Active head rotation in Benign Paroxysmal Positional vertigo. Braz J Otorhinolaryngol 2009;75(4): 586-92.

2. Parnes LS, Agrawal SK, Atlas J. Diagnosis and management of benign paroxysmal vertigo (BPPV). CMAJ. 2003;169(7):681-93.

3. Celebisoy N, Bayam E, Gulec F, Kose T, Akyurekli $\mathrm{O}$. Balance in posterior and horizontal canal type benign paroxysmal positional vertigo before and after canalith repositioning maneuvers. Gait \& Posture 2009; 29: 520-23.

4. Chung $\mathrm{KW}$, Park $\mathrm{KN}$, $\mathrm{Ko} \mathrm{MH}$, Jeon $\mathrm{HK}$, et al Incidence of horizontal canal benign paroxysmal positional vertigo as a function of the duration of symptoms. Otology \& Neurotology 2009; 30:20205.

5. Chiou WY, Lee HL, Tsai SC, Yu TH, Lee XX. A single therapy for all subtypes of horizontal canal positioning vertigo. Laryngoscope 2005; 115:1432-35. 
6. Bhattacharyya N, Baugh RF, Orvidas L, et al. Clinical Practice Guidelines: Benign paroxysmal positional vertigo. Otolaryngology-HNS 2008; 139: S47-S81

7. Fife TD, Iverson DJ, Lempert $T$, et al. Practice parameter: Therapies for benign paroxysmal positional vertigo (an evidence-based review): Report of the Quality Standard Subcommittee of the American Academy of Neurology. Neurology 2008; 70:2067-73

8. Escher A, Ruffieux C, Maire R. Efficacy Of The Barbecue Manoeuvre In Benign Paroxysmal Vertigo Of The Horizontal Canal. Eur Arch Otorhinolaryngol 2007; 264: 1239-41

9. Herdman SJ, Tusa RJ, Zee DS, Proctor LR, Mattox DE. Single treatment approach to benign paroxysmal positional vertigo . Arch Otolaryngol Head Neck Surg. 1993; 119: 450-54

10. Choung $\mathrm{YH}$, Shin YR, Kahng H, Park K, Choi SJ. 'Bow and Lean test to Determine the Affected Ear of Horizontal Canal Benign Paroxysmal Positional Vertigo. Laryngoscope 2006; 116:1776-81

11. Moon SY, Kim JS, Kim BK, Kim JI, et al. clinical characteristic of benign paroxysmal positional vertigo in Korea: A multicenter study. J Korean Med Sci 2006; 21: 539-43.

12. Koo JW, moon IJ, Shim WS, Moon SY, Kim JS. Value of Lying-down Nystagmus in the lateralization of horizontal semicircular canal banign paroxysmal positional vertigo. Otology \& Neurotology 2006;27: 367-71.

13. Bibsdorff AR, Debatisse D. Localizing sign in positional vertigo due to lateral canal cupulolithasis. Neurology 2001; 57:1085-88

14. Heidenreich KD, Beaudoin K, Whie JA. Can lateral canal benign paroxysmal vertigo mimic $s$ false positive head trust test? Am J Otolaryngology-Head and Neck Medicine Surgery 2009;
15. Cakir BO, Ercan I, Cakir ZA, Civelek S, et al. what is the true incidence of horizontal semicircular canal benign paroxysmal positional vertigo? otolaryngol-HNS 2006; 134:451-54

16. Giacomini PG, Ferraro S, Di Girolamo S, Villanova I, Ottaviani F. Benign Paroxysmal Positional Vertigo after intense physical activity: a report of nine cases. In Case report. Eur Arch Otorhinolaryngol 2009; 266: 1831-35

17. Hain TC. Lateral canal BPPV. Last modified 2009, November 21 (cited 2010 Jan 13). Available from http://www.dizziness-andbalance.com/disorders/bppv/lcanalbppv.htm

18. Herdman SJ, Tusa RJ. Horizontal canal BPPV. In: Diagnosis and treatment of benign paroxysmal positional vertigo. ICS Medical Corporation, Schaumbur, Illinois 1999: 18-23.

19. Lee SH, Choi KD, Jeong SH, Oh YM, Koo JW, Kim JS. Nystagmus during neck flexion in the pitch plane in benign paroxysmal positional vertigo involving the horizontal canal. Journal of the Neurological Sciences 2007; 256: 75-80.

20. Appiani CG, Catania G, Gagliardi M, Cuiuli G. repositioning maneuver for the treatment of the apogeotropic variant of horizontal canal benign paroxysmal positional vertigo. Otology \& Neurotology 2005; 26:257-60.

21. Andradi S. Terapi vertigo. Vertigo, patofisiologi, diagnosis dan terapi. Kelompok Studi Vertigo PERDOSSI.

22. Bahadir C, Diracoglu D, Kurtulus D, Garipoglu I. Efficacy of canalith repositioning maneuvers for benign paroxysmal positional vertigo. Clinical Chiropractic 2009; 12: 95-100. 